\title{
Reorientasi Penegakan Hukum Pidana Lingkungan Hidup melalui Perjanjian Penangguhan Penuntutan \\ Azam Hawari ${ }^{1}$, Deni Daniel ${ }^{2}$, dan Marsya Mutmainah Handayani ${ }^{3}$
}

\begin{abstract}
Abstrak
Penegakan hukum pidana lingkungan sejatinya ditujukan untuk mewujudkan tujuan dalam UU 32/2009. Namun, proses persidangan seringkali rumit, mahal, dan lama sementara lingkungan yang tercemar dan/atau rusak membutuhkan pemulihan yang cepat dan tepat. Hal ini membuat rekonstruksi paradigma penegakan hukum pidana, khususnya lingkungan hidup dibutuhkan. Oleh karena itu, tulisan ini mencoba menggagas Perjanjian Penangguhan Penuntutan sebagai salah satu solusi alternatif dalam sistem peradilan pidana lingkungan hidup. Perjanjian Penangguhan Penuntutan dapat menjadi salah satu solusi alternatif terhadap permasalahan proses ajudikasi, khususnya pada pelaku korporasi yang selama ini belum optimal karena dapat menciptakan efektivitas dan efisiensi penegakan hukum pidana lingkungan.
\end{abstract}

Kata Kunci: Hukum Pidana Lingkungan, Penegakan Hukum Pidana Lingkungan, Perjanjian Penangguhan Penuntutan

\begin{abstract}
Environmental crime enforcement aims to realize the purpose of Law No. 32 of 2009. While the criminal proceeding is complicated, costly, and takes a long time, the environment requires quick and precise recovery. Therefore, paradigm-shifting of environmental crime enforcement is required. This paper aims to introduce a Deferred Prosecution Agreement as an alternative solution to the environmental justice system. Deferred Prosecution Agreement can be utilized as an alternative solution to address adjudication problems, especially in corporate criminal liability, which has not been optimal as it can raise effectiveness and efficiency on the enforcement of an environmental crime.
\end{abstract}

Keywords: Environmental Criminal Law, Enforcement of Environmental Criminal Law, Deferred Prosecution Agreement

\footnotetext{
${ }^{1}$ Penulis merupakan analis hukum di bidang lingkungan, kesempatan ekonomi, dan kesejahteraan masyarakat.

${ }^{2}$ Penulis merupakan lulusan Fakultas Hukum Universitas Indonesia.

${ }^{3}$ Penulis merupakan peneliti pada Yayasan Pengembangan Hukum Lingkungan Indonesia/Indonesian Center for Environmental Law (ICEL).
} 


\section{Pendahuluan}

Walaupun undang-Undang Nomor 32 Tahun 2009 tentang Perlindungan dan Pengelolaan Lingkungan Hidup (UU PPLH) tidak sempurna, ia merupakan hukum lingkungan terbaik yang dimiliki Indonesia saat ini karena telah sangat komprehensif mengatur berbagai hal terkait perlindungan dan pengelolaan lingkungan hidup. Salah satunya adalah penguatan pada penegakan hukum pidana, berupa perlindungan korban (dalam hal ini adalah lingkungan hidup) dengan diaturnya sanksi perbaikan akibat tindak pidana sebagai pidana tambahan. ${ }^{4}$ Selain itu, UU PPLH juga telah mengakui pertanggungjawaban pidana korporasi. ${ }^{5}$

Meski demikian, penegakan hukum pidana lingkungan hidup masih dianggap cukup lemah. Bahkan masih jauh dari terwujudnya tujuan yang dicitacitakan UU PPLH itu sendiri. Sebagaimana ditegaskan oleh Keraf bahwa:

"segala hal yang diatur dalam UU 32/2009, mulai dari perencanaan sampai pada penegekan hukum, khususnya pidana, tidak lain tidak bukan bertujuan untuk mecapai sasaran akhir menjamin terjaganya daya dukung dan daya tampung lingkungan hidup."6

Contohnya saja, dari 70 perkara pidana lingkungan hidup yang diputus pada 2002 sampai 2015, 43 persen terdakwa divonis bebas; 40 persen dihukum dengan percobaan; 13 persen terdakwa dihukum penjara dan denda; 2 persen onslag van gewijsde (lepas dari tuntutan hukum); dan 2 persen tuntutan ditolak. ${ }^{7}$ Hal ini menunjukkan bahwa pemulihan belum menjadi arus utama dalam pemidanaan lingkungan hidup.

Di samping itu, sanksi pemulihan hanyalah berupa sanksi pidana tambahan, yang penjatuhannya sangat bergantung pada pemahaman atas lingkungan hidup dan diskresi Majelis Hakim yang memeriksa perkara. Hal ini menimbulkan ketidakpastian atas dijatuhkannya sanksi pemulihan tersebut. Selain itu, proses persidangan yang dapat memakan waktu tahunan hingga putusan berkekuatan hukum tetap, pembuktian yang rumit dalam perkara lingkungan hidup yang kental dengan bukti ilmiah, terlebih yang dilakukan oleh korporasi, dan berbiaya tidak sedikit dapat menunda pelaksanaan pemulihan lingkungan

${ }^{4}$ Indonesia. Undang-Undang Perlindungan dan Pengelolaan Lingkungan Hidup, UU No. 32 Tahun 2009, LN No. 140 Tahun 2009, TLN No. 5059, Pasal 119 huruf c.

${ }^{5}$ Ibid., pasal 1 angka 32, Pasal 116-119.

${ }^{6}$ Sony Keraf, Etika Lingkungan Hidup, (Jakarta: PT Kompas Media Nusantara, 2010), hlm. 251.

${ }^{7} \mathrm{NN}$, “4 Masalah yang Dihadapi Penyidik Kasus Lingkungan Hidup” dalam https:/ / www.hukumonline.com/berita/baca/lt573a6ea417e97/4-masalah-yang-dihadapi-penyidik-kasus-lingkungan-hidup, diakses tanggal 31 Januari 2019. 
hidup. Belum lagi pelbagai masalah eksekusi putusan pengadilan menimbulkan kebutuhan untuk menemukan suatu solusi alternatif akan mekanisme yang berorientasi terhadap pemulihan lingkungan secara efektif dan efisien. Perjanjian Penangguhan Penuntutan atau Deferred Prosecution Agreement (DPA) dapat menjadi salah satu solusi alternatif untuk mewujudkan peradilan yang cepat, mudah, berbiaya ringan, dan berorientasi pada pemulihan.

Pada pokoknya, Perjanjian Penangguhan Penuntutan merupakan kesepakatan hasil negosiasi yang dilakukan oleh jaksa penuntut umum dan pelaku korporasi atau kuasa hukumnya untuk menyelesaikan beberapa kewajiban sebagai akibat dari dugaan tindak pidana. ${ }^{8}$ Apabila korporasi melaksanakan kewajiban dalam Perjanjian Penangguhan Penuntutan, maka proses penuntutan akan ditunda atau bahkan benar-benar tidak dituntut. Konsep Perjanjian Penangguhan Penuntutan dapat menjadi solusi alternatif penegakan hukum pidana lingkungan hidup untuk memulihkan pencemaran ataupun kerusakan lingkungan hidup karena memungkinkan pemulihan kerusakan lingkungan hidup yang lebih terencana. Di samping itu, Perjanjian
Penangguhan Penuntutan juga berpotensi mengefektifkan penegakan hukum pidana korporasi karena memberikan insentif kepada korporasi dengan memotong proses persidangan biasa yang cenderung lama, mengurangi biaya berperkara, dan menghindari reputasi buruk. ${ }^{9}$ Pasalnya, hasil studi empiris menunjukkan bahwa penyidikan terhadap perusahaan mendorong penurunan nilai saham yang signifikan. ${ }^{10}$ Dalam proses ini, perusahaan akan dihadapkan pada ketidakpastian-situasi yang tidak disukai oleh investor dan pasar modal. Dengan kata lain, Perjanjian Penangguhan Penuntutan tidak hanya bermanfaat bagi penegakan hukum pidana lingkungan hidup tetapi juga korporasi itu sendiri. Oleh karena itu, tulisan ini akan mengeksplorasi kemungkinan diaplikasikannya konsep Perjanjian Penangguhan Penuntutan dalam penegakan hukum pidana lingkungan hidup di Indonesia.

Lebih lanjut, dalam mengeksplorasi kemungkinan tersebut, Penulis terlebih dahulu akan mengevaluasi pertanggungjawaban pidana korporasi dan orientasi pemulihan dalam 8 kasus yang telah diputus (baik yang telah berkekuatan hukum tetap maupun belum) sepanjang tahun 2010-2019. Kemudian, penulis

\footnotetext{
${ }^{8}$ Rachel Delaney, "Congressional Legislation: The Next Step for Corporate Deferred Prosecution Agreements", Marquette Law Review, Vol. 93, No. 2, (2009), hlm. 878.

${ }^{9}$ Ibid., hlm. 879.

${ }^{10}$ Joseph Warin \& Andrew S. Boutros, "Deferred Prosecution Agreements: A View from the Trenches and a Proposal for Reform", Virginia Law Review, Vol. 93, (2007), hlm. 129.
} 
akan mendiskusikan konsep Perjanjian Penangguhan Penuntutan sebagai jalan pintas penegakan hukum pidana berorientasi pemulihan. Dilanjutkan dengan potensi penerapan Perjanjian Penangguhan Penuntutan dalam pertanggungjawaban pidana korporasi dalam perkara lingkungan hidup di Indonesia. Terakhir, tulisan ini akan ditutup dengan kesimpulan bahwa Perjanjian Penangguhan Penuntutan dapat diaplikasikan dan mengefektifkan penegakan hukum pidana lingkungan hidup di Indonesia.

\section{Pertanggungjawaban Pidana Kor- porasi dalam Perkara Lingkungan Hidup Belum Berorientasi Pada Pe- mulihan}

Kebijakan hukum pidana atau criminal policy merupakan pengorganisasian rasional oleh masyarakat untuk mengendalikan kejahatan. ${ }^{11}$ Dalam hal ini, formulasi kebijakan hukum pidana harus diperlakukan sebagai bagian dari kebijakan sosial dimana kebijakan pidana memerlukan keterpaduan antara penggunaan sarana hukum pidana serta sarana di luar hukum pidana ${ }^{12}$ dan mem- pertimbangkan efektivitas dan proporsionalitas terhadap tujuan yang hendak dicapai. ${ }^{13}$

Lebih lanjut, Takdir Rahmadi menyatakan bahwa penjatuhan sanksi pidana dalam tindak pidana lingkungan hidup bertujuan untuk "melindungi lingkungan hidup secara keseluruhan maupun unsur-unsur dalam lingkungan hidup seperti hutan satwa, lahan, udara, dan air serta manusia." ${ }^{14}$ Ditambah lagi, fakta bahwa kasus-kasus pidana lingkungan hidup banyak yang dilakukan oleh korporasi, Loebby Loeqman menyarankan sanksi pidana terhadap korporasi perlu "mempertimbangkan keserasian antara perlindungan terhadap lingkungan hidup di satu pihak, dan pertanggungjawaban pidana di pihak lainnya." 15

Sepanjang tahun 2010 sampai 2019, Penulis menemukan setidaknya 8 kasus yang mengadili korporasi dan telah diputus baik yang telah berkekuatan hukum tetap maupun belum. Putusanputusan tersebut penulis rangkum dalam Tabel 1, berikut ini. hlm. 4

${ }^{11}$ G. Peter Hoefnagels, The Other Side of Criminology, (Deventer, Hollend: Kluwer, 1973), hlm. 57.

${ }^{12}$ Barda Nawawi Arief, Bunga Rampai Kebijakan Hukum Pidana, (Bandung: Citra Aditya Bakti, 1996),

${ }^{13}$ Muladi dan Barda Nawawi Arief, Teori-teori dan Kebijakan Pidana, (Bandung: Citra Aditya Bakti, 1996), hlm. 102.

${ }^{14}$ Takdir Rahmadi, Hukum Lingkungan di Indonesia, Cetakan ke-4, (Jakarta: PT Raja Grafindo Persada, 2014), hlm. 221.

${ }^{15}$ Loeqman, Loebby. “Tanggung Jawab Pidana Korporasi dalam Tindak Pidana Lingkungan Hidup," Jurnal Hukum dan Pembangunan, Vol. 19, No. 3, (1989), hlm. 246. 
Tabel 1. Ringkasan Perkara Pidana Lingkungan Hidup Korporasi 2010-2019

\begin{tabular}{|c|c|c|c|c|c|}
\hline No. & Nama Perkara & $\begin{array}{l}\text { Tindak } \\
\text { Pidana }\end{array}$ & Tuntutan JPU & Putusan Hakim & Durasi \\
\hline \multirow[t]{2}{*}{1} & \multirow{2}{*}{\begin{tabular}{|ll} 
PT & Adei Plantation: \\
1. & 228/Pid. \\
& Sus/2013/ \\
& PN.Plw tanggal \\
& 9 September \\
& 2014 \\
2. & 286/PID. \\
& SUS/2014/ \\
& PT.PBR tanggal \\
& 9 Januari 2015 \\
3. & 2042K/Pid. \\
& Sus/2015 tang- \\
& gal 14 Maret \\
& 2016
\end{tabular}} & \multirow[t]{2}{*}{$\begin{array}{l}\text { Ps } 99 \text { UU } \\
32 / 2009\end{array}$} & $\begin{array}{l}\text { Pidana den- } \\
\text { da sebesar Rp } \\
5.000 .000 .000,00\end{array}$ & $\begin{array}{l}\text { Pidana denda sebesar Rp } \\
\text { 1.500.000.000,00 subsider } 5 \\
\text { bulan kurungan kepada Tan } \\
\text { Kei Yoong. }\end{array}$ & \multirow{2}{*}{$\begin{array}{l}\text { Perkara telah di- } \\
\text { daftarkan sejak } \\
24 \text { Desember } 2013 \\
\text { dengan durasi } 812 \\
\text { hari. }\end{array}$} \\
\hline & & & $\begin{array}{l}\text { Pidana tambahan: } \\
\text { perbaikan akibat } \\
\text { tindak pidana untuk } \\
\text { memulihkan lahan } \\
\text { yang rusak akibat } \\
\text { kebakaran lahan se- } \\
\text { luas } 40 \text { ha melalui } \\
\text { pemberian kompos, } \\
\text { dengan biaya sebesar } \\
\text { Rp15.794.238.630,00 }\end{array}$ & $\begin{array}{l}\text { Pidana tambahan: } \\
\text { perbaikan akibat tindak } \\
\text { pidana untuk memulihkan } \\
\text { lahan yang rusak akibat } \\
\text { kebakaran lahan seluas } 40 \\
\text { ha melalui pemberian kom- } \\
\text { pos, dengan biaya sebesar } \\
\text { Rp15.141.826.779,325. }\end{array}$ & \\
\hline \multirow[t]{2}{*}{2} & \multirow{2}{*}{$\begin{array}{l}\text { PT Albasi Priangan } \\
\text { Lestari: } \\
\text { 1. } \\
\text { 155/PID. } \\
\text { SUS/2013/ } \\
\text { PN.CMS tang- } \\
\text { gal } 4 \text { Septem- } \\
\text { ber 2013 } \\
\text { 2. } \\
\text { 344/PID/2013/ } \\
\text { PT BDG tang- } \\
\text { gal 18 Novem- } \\
\text { ber 2013 } \\
\text { 3. } \\
\text { 814K/PID. } \\
\text { SUS/2014 tang- } \\
\text { gal 22 Oktober } \\
\text { 2014 }\end{array}$} & \multirow[t]{2}{*}{$\begin{array}{l}\text { PS } 100 \text { UU } \\
32 / 3009\end{array}$} & $\begin{array}{l}\text { Pidana denda sebe- } \\
\text { sar Rp350.000.000,00. }\end{array}$ & $\begin{array}{l}\text { Pidana Denda } \\
\text { Rp1.000.000.000,00 dengan } \\
\text { ketentuan apabila denda } \\
\text { tersebut tidak dibayar maka } \\
\text { sebagian asset/harta PT. AL- } \\
\text { BASI PRIANGAN LESTARI, } \\
\text { disita dan dijual lelang untuk } \\
\text { sekedar cukup untuk memba- } \\
\text { yar jumlah denda dimaksud. }\end{array}$ & \multirow[t]{2}{*}{$\begin{array}{l}\text { Perkara telah di- } \\
\text { daftarkan sejak } 11 \\
\text { Juni } 2013 \text { dengan } \\
\text { durasi } 591 \text { hari. }\end{array}$} \\
\hline & & & $\begin{array}{l}\text { Pidana tambahan: } \\
\text { Perbaikan akibat } \\
\text { tindak pidana yaitu } \\
\text { memperbaiki Insta- } \\
\text { lasi Pengolahan Air } \\
\text { Limbah (IPAL) dan } \\
\text { pencabutan izin ling- } \\
\text { kungan. }\end{array}$ & $\begin{array}{l}\text { Pidana tambahan: } \\
\text { Memperbaiki kinerja Insta- } \\
\text { lasi Pengolahan Air Limbah } \\
\text { (IPAL) sehingga air limbah } \\
\text { yang dibuang ke media ling- } \\
\text { kungan sudah memenuhi } \\
\text { ketentuan baku mutu. } \\
\text { Memeriksa kadar parameter } \\
\text { baku mutu alir limbah cair } \\
\text { secara periodik, sekurangnya } \\
\text { sekali dalam sebulan atas bia- } \\
\text { ya perusahaan pada laborato- } \\
\text { rium rujukan; }\end{array}$ & \\
\hline
\end{tabular}


Azam Hawari, Deni Daniel, dan Marsya Mutmainah Handayani

Reorientasi Penegakan Hukum Pidana Lingkungan Hidup melalui Perjanjian Penangguhan Penuntutan

\begin{tabular}{|c|c|c|c|c|c|}
\hline No. & Nama Perkara & $\begin{array}{l}\text { Tindak } \\
\text { Pidana }\end{array}$ & Tuntutan JPU & Putusan Hakim & Durasi \\
\hline & & & & $\begin{array}{l}\text { Menyampaikan laporan } \\
\text { tentang debit harian kadar } \\
\text { parameter baku mutu limbah } \\
\text { cair, produksi dan atau bahan } \\
\text { baku bulanan senyatanya, se- } \\
\text { kurang-kurangnya tiga bulan } \\
\text { sekali kepada Walikota Banjar } \\
\text { dengan tembusan kepada } \\
\text { Menteri Negara Lingkungan } \\
\text { Hidup. }\end{array}$ & \\
\hline 3 & $\begin{array}{l}\text { PT KALISTA } \\
\text { ALAM: } \\
\text { 131/Pid.B/2013/ } \\
\text { PN.MBO tanggal } 15 \\
\text { Juli 2014 } \\
\text { 201/PID/2014/ } \\
\text { PT BNA tanggal } 19 \\
\text { November 2014 } \\
\text { 1554K/Pid. } \\
\text { Sus/2015 tanggal } 5 \\
\text { April 2016 }\end{array}$ & $\begin{array}{l}\text { Pasal } 108 \\
\text { UU 32/2009 }\end{array}$ & $\begin{array}{l}\text { Pidana den- } \\
\text { da sebesar } \\
\text { Rp3.000.000.000,00 }\end{array}$ & $\begin{array}{l}\text { Pidana denda sebesar } \\
\text { Rp3.000.000.000,00 }\end{array}$ & $\begin{array}{l}\text { Perkara telah di- } \\
\text { daftarkan sejak } 27 \\
\text { September } 2013 \\
\text { dengan durasi } 922 \\
\text { hari. }\end{array}$ \\
\hline \multirow[t]{2}{*}{4} & \multirow{2}{*}{ 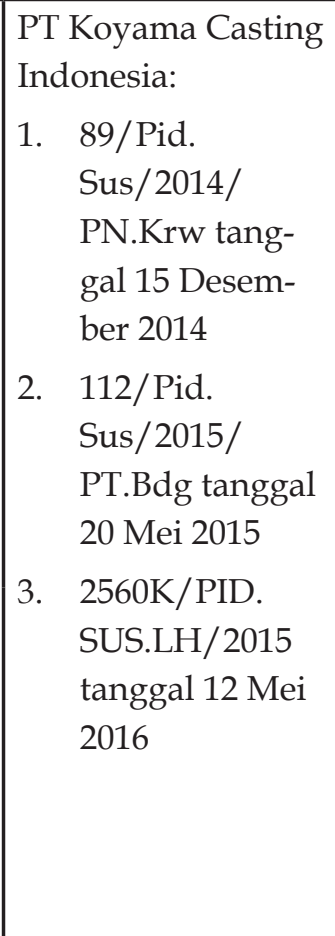 } & \multirow[t]{2}{*}{$\begin{array}{l}\text { PS } 103 \text { UU } \\
32 / 2009\end{array}$} & $\begin{array}{l}\text { Menjatuhkan Pidana } \\
\text { terhadap Terdakwa } \\
\text { Shigemi Koyama de- } \\
\text { ngan Pidana Penjara } \\
\text { selama } 2 \text { tahun Pen- } \\
\text { jara dengan perintah } \\
\text { agar Terdakwa di- } \\
\text { tahan dan memba- } \\
\text { yar Denda sebesar } \\
\text { Rp1.000.000.000,00 } \\
\text { subsidair } 6 \text { bulan ku- } \\
\text { rungan. }\end{array}$ & $\begin{array}{l}\text { Pidana denda sebesar } \\
\text { Rp1.000.000.000,00 dengan } \\
\text { ketentuan tersebut tidak } \\
\text { dibayar diganti dengan pe- } \\
\text { rampasan asset PT KCI oleh } \\
\text { Penuntut Umum untuk dijual } \\
\text { lelang menutupi denda se- } \\
\text { jumlah tersebut }\end{array}$ & \multirow[t]{2}{*}{$\begin{array}{l}\text { Perkara telah di- } \\
\text { daftarkan sejak } 4 \\
\text { April } 2014 \text { dengan } \\
\text { durasi } 770 \text { hari. }\end{array}$} \\
\hline & & & - & $\begin{array}{l}\text { Pidana tambahan: } \\
\text { Memerintahkan kepada Ter- } \\
\text { dakwa PT. KCI melakukan } \\
\text { pengelolaan limbah dengan } \\
\text { badan usaha yang mempu- } \\
\text { nyai izin dalam pengelolaan } \\
\text { limbah }\end{array}$ & \\
\hline
\end{tabular}




\begin{tabular}{|c|c|c|c|c|c|}
\hline No. & Nama Perkara & $\begin{array}{l}\text { Tindak } \\
\text { Pidana }\end{array}$ & Tuntutan JPU & Putusan Hakim & Durasi \\
\hline & & & & $\begin{array}{l}\text { Memerintahkan kepada PT. } \\
\text { KCI untuk melaksanakan } \\
\text { pelaporan secara berkala } 1 \\
\text { (satu) kali } 6 \text { (enam) bulan atas } \\
\text { hasil pengelolaan dan peman- } \\
\text { tauan lingkungan }\end{array}$ & \\
\hline \multirow[t]{2}{*}{5} & $\begin{array}{l}\text { PT Karawang Pri- } \\
\text { ma Sejahtera Steel } \\
\text { 1. No.434/ } \\
\text { Pid.B/2011/P. } \\
\text { Krw. tanggal } 09 \\
\text { Februari } 2012\end{array}$ & \multirow[t]{2}{*}{$\begin{array}{l}\text { Ps } 104 \text { UU } \\
32 / 2009\end{array}$} & $\begin{array}{l}\text { Pidana penjara } \\
\text { selama } 5 \text { bulan, } \\
\text { dan pidana denda } \\
\text { Rp1.000.000.000,00 } \\
\text { Subsidair } 6 \text { bulan } \\
\text { kurungan. }\end{array}$ & $\begin{array}{l}\text { Pidana denda sebesar } \\
\text { Rp500.000.000,00. }\end{array}$ & \multirow[t]{2}{*}{$\begin{array}{l}\text { Perkara telah di- } \\
\text { daftarkan sejak } \\
9 \text { Februari } 2012 \\
\text { dengan durasi } 713 \\
\text { hari (dari putusan } \\
\text { tngkat 1). }\end{array}$} \\
\hline & $\begin{array}{ll}\text { 2. } & \text { 170/PID.SUS/ } \\
& \text { 2012/PT.Bdg } \\
\text { tanggal } 28 \mathrm{Mei} \\
\\
2012 \\
\text { 3. } & \text { 1405K/Pid. } \\
& \text { Sus/2013 tang- } \\
\text { gal } 20 \text { Januari } \\
2014\end{array}$ & & $\begin{array}{l}\text { Pidana Tambahan: } \\
\text { Menjatuhkan pidana } \\
\text { tambahan berupa } \\
\text { perbaikan akibat } \\
\text { tindak pidana yang } \\
\text { dalam pelaksanaan- } \\
\text { nya di bawah penga- } \\
\text { wasan Badan Ling- } \\
\text { kungan Hidup Ka- } \\
\text { bupaten Karawang. }\end{array}$ & - & \\
\hline \multirow[t]{2}{*}{6} & \multirow[t]{2}{*}{$\begin{array}{l}\text { PT Platindo Agro } \\
\text { Subur: } \\
\text { 1/Pid.Sus- } \\
\text { LH/2016/PN. Rta } \\
\text { tanggal 26 Juli } 2016\end{array}$} & \multirow[t]{2}{*}{$\begin{array}{l}\text { Ps } 99 \text { ayat } \\
\text { (1) UU } \\
32 / 2009\end{array}$} & $\begin{array}{l}\text { Pidana den- } \\
\text { da sebesar } \\
\text { Rp2.000.000.000,00 } \\
\text { apabila pidana den- } \\
\text { da tidak dibayar } \\
\text { maka harta kekaya- } \\
\text { an/aset korporasi } \\
\text { dirampas sesuai per- } \\
\text { aturan perundang- } \\
\text { undangan yang } \\
\text { berlaku. }\end{array}$ & $\begin{array}{l}\text { Pidana denda } \\
\text { Rp1.500.000.000,00. }\end{array}$ & \multirow[t]{2}{*}{$\begin{array}{l}\text { Perkara telah di- } \\
\text { daftarkan sejak } 28 \\
\text { Maret } 2016 \text { dengan } \\
\text { durasi } 120 \text { hari. }\end{array}$} \\
\hline & & & $\begin{array}{l}\text { Pidana tambahan: } \\
\text { pewajiban mengerja- } \\
\text { kan apa yang dilalai- } \\
\text { kan tanpa hak yaitu } \\
\text { melengkapi sarana } \\
\text { dan prasarana pen- } \\
\text { cegahan kebakaran } \\
\text { hutan dan/atau la- } \\
\text { han yang }\end{array}$ & $\begin{array}{l}\text { Pidana tambahan: } \\
\text { Menjatuhkan pidana tambah- } \\
\text { an atau tindakan tata tertib } \\
\text { berupa pewajiban mengerja- } \\
\text { kan apa yang dilalaikan tanpa } \\
\underline{\text { hak. }}\end{array}$ & \\
\hline
\end{tabular}


Azam Hawari, Deni Daniel, dan Marsya Mutmainah Handayani

Reorientasi Penegakan Hukum Pidana Lingkungan Hidup melalui Perjanjian Penangguhan Penuntutan

\begin{tabular}{|c|c|c|c|c|c|}
\hline No. & Nama Perkara & $\begin{array}{l}\text { Tindak } \\
\text { Pidana }\end{array}$ & Tuntutan JPU & Putusan Hakim & Durasi \\
\hline & & & $\begin{array}{l}\text { memadai serta mem- } \\
\text { perbaiki managemen } \\
\text { sumber daya manu- } \\
\text { sia terkait pencegah- } \\
\text { an kebakaran lahan/ } \\
\text { hutan dan membuat } \\
\text { dan merevisi laporan } \\
\text { terkait lingkungan } \\
\text { hidup yang menjadi } \\
\text { kewajiban terdakwa. }\end{array}$ & & \\
\hline \multirow[t]{2}{*}{7} & \multirow{2}{*}{$\begin{array}{l}\text { PT National Sago } \\
\text { Prima: } \\
\text { 547/Pid.Sus/2014/ } \\
\text { PN.Bls tanggal } 19 \\
\text { Januari 2015 } \\
\text { 27/PID.SUS/2015/ } \\
\text { PT PBR tanggal 1 } \\
\text { Juni } 2015\end{array}$} & \multirow[t]{2}{*}{$\begin{array}{l}\text { Ps } 99 \text { ayat } \\
\text { (1) UU } \\
32 / 2009\end{array}$} & $\begin{array}{l}\text { Pidana den- } \\
\text { da sebesar } \\
\text { Rp5.000.000.000,00. }\end{array}$ & $\begin{array}{l}\text { Pidana denda sebesar } \\
\text { Rp2.000.000.000,00. }\end{array}$ & \multirow{2}{*}{$\begin{array}{l}\text { Perkara telah di- } \\
\text { daftarkan sejak } 26 \\
\text { November } 2014 \\
\text { dengan durasi } 186 \\
\text { hari. }\end{array}$} \\
\hline & & & $\begin{array}{l}\text { Pidana Tambahan: } \\
\text { Perbaikan akibat } \\
\text { tindak pidana untuk } \\
\text { memulihkan lahan } \\
\text { yang rusak akibat } \\
\text { kebakaran lahan, } \\
\text { dengan biaya sebe- } \\
\text { sar Rp1.046.018.923. } \\
000,00 \text {. }\end{array}$ & $\begin{array}{l}\text { Pidana Tambahan: } \\
\text { kewajiban melengkapi sarana } \\
\text { pencegahan dan penang- } \\
\text { gulangan kebakaran sesuai } \\
\text { dengan petunjuk standari- } \\
\text { sasi sarana pencegahan dan } \\
\text { penanggulangan kebakaran } \\
\text { hutan dengan pengawasan } \\
\text { Badan Lingkungan Hidup } \\
\text { Kabupaten Kepulauan Me- } \\
\text { ranti dalam jangka waktu } 1 \\
\text { tahun. }\end{array}$ & \\
\hline 8 & $\begin{array}{l}\text { PT. Surya Panen } \\
\text { Subur: } \\
\text { 54/Pid.Sus/2014/ } \\
\text { PN.MBO tanggal } 25 \\
\text { Januari } 2016 \\
\text { 61/PID/2016/PT- } \\
\text { BNA tanggal 12 Juli } \\
2016 \\
\text { 2657K/Pid. } \\
\text { Sus/2016 tanggal } 9 \\
\text { Oktober } 2017\end{array}$ & $\begin{array}{l}\text { Ps } 108 \text { UU } \\
32 / 2009\end{array}$ & $\begin{array}{l}\text { Pidana den- } \\
\text { da sebesar } \\
\text { Rp4.000.000.000,00. }\end{array}$ & $\begin{array}{l}\text { Pidana denda sebesar } \\
\text { Rp3.000.000.000,00. }\end{array}$ & $\begin{array}{l}\text { Perkara telah di- } \\
\text { daftarkan sejak } 7 \\
\text { Mei } 2014 \text { dengan } \\
\text { durasi } 631 \text { hari. }\end{array}$ \\
\hline
\end{tabular}


Data dalam Tabel 1 menunjukkan bahwa penegakan hukum lingkungan hidup khususnya pertanggungjawaban korporasi memakan waktu yang lama dan belum berorientasi pada pemulihan. Hal ini dapat dilihat dari rata-rata durasi proses peradilan yang cukup lama, 593 hari. Selain itu, hanya 1 dari 8 perkara yang dijatuhkan sanksi pidana tambahan pemulihan kepada terpidana, 1 perkara sudah dijatuhkan pemulihan dalam perkara perdatanya (PT Kalista Alam), dan 4 perkara dijatuhkan sanksi pidana tambahan pemberian kewajiban mengerjakan apa yang dilalaikan tanpa hak. Sanksi denda yang dijatuhkan pada terpidana lingkungan hidup memang sangat besar, rata-rata dari kedelapan kasus adalah Rp1.500.000.000,00, hal ini mengingat ancaman pidana yang tinggi dalam undang-undang karena dampak pencemaran atau kerusakan lingkungan hidup yang ditimbulkan juga besar. Namun perlu digarisbawahi bahwa sanksi pidana denda tidak dapat digunakan untuk pemulihan lingkungan hidup yang tercemar atau rusak, melainkan hanyalah penerimaan negara bukan pajak yang berlaku pada kejaksaan. ${ }^{16}$ Pengelolaannya pun dilakukan oleh Menteri Keuangan. ${ }^{17}$
Lebih jauh lagi, pidana tambahan perbaikan akibat tindak pidana ditemukan dalam perkara PT Adei Plantation berupa pemulihan lahan yang rusak akibat kebakaran lahan seluas 40 hektare melalui pemberian kompos, dengan biaya sebesar Rp15.141.826.779,325. Total durasi proses persidangan perkara ini sejak diregister di Pengadilan Negeri sampai ke Mahkamah Agung memakan waktu 812 hari kalender. Waktu yang lama ini belum termasuk waktu terjadinya tindak pidana, waktu penyelidikan dan penyidikan, dan waktu pelaksanaan/eksekusi putusan. Padahal pencemaran atau kerusakan lingkungan hidup akan terus terjadi jika tidak segera ditanggulangi atau diperbaiki. Pencemaran atau kerusakan lingkungan hidup yang berlangsung terus pun dapat menyebabkan kerugian ekologis dan ekonomi (interim loss) yang tidak sedikit. Pasalnya, hingga kini aparat penegak hukum masih kebingungan melaksanakan atau eksekusi putusan lingkungan hidup, terlebih pada putusan perkara perdata lingkungan hidup. Pelaksanaan atau eksekusi putusan paling tidak memiliki tiga hambatan mendasar, yakni: 1) dukungan legislatif dan eksekutif yang minim dalam memberikan jaminan

\footnotetext{
${ }^{16}$ Indonesia, Pemerintah Indonesia, Peraturan Pemerintah tentang Jenis dan Tariff Atas Jenis Penerimaan Negara Bukan Pajak Yang Berlaku Pada Kejaksaan Republic Indonesia, PP No. 39 Tahun 2016, Pasal 1 (1) huruf c.

${ }^{17}$ Indonesia, Undang-Undang tentang Penerimaan Negara Bukan Pajak, UU No. 9 Tahun 2018, LN No. 147 Tahun 2018. TLN No. 6245. Pasal 15.
} 
dan kepastian kelancaran pelaksanaan atau eksekusi putusan, 2) tidak adanya dukungan perundang-undangan dalam pelaksanaan atau eksekusi putusan secara efektif dan efisien, dan 3) kompetensi juru sita yang lemah dalam melaksanakan tugas dan wewenangnya. ${ }^{18}$

Di samping itu, pertimbangan atas penjatuhan pidana tambahan pemulihan dalam putusan ini masih minim karena hanya memenuhi tuntutan jaksa penuntut umum yang menuntut pemulihan lahan yang rusak akibat kebakaran seluas 40 hektar melalui pemberian kompos, dengan biaya sebesar Rp15.141.826.779,325 dan menyangkal pembelaan kuasa hukum terdakwa yang hanya bersifat formal, ${ }_{19}^{19}$ tanpa pertimbangan mengenai kepentingan lingkungan hidup itu sendiri dan mengeksplorasi mekanisme pemulihan. Hal ini merupakan akibat dari sifat alami pidana tambahan yang merupakan diskresi hakim. Walaupun dalam perkara pidana lingkungan hidup hakim diharapkan bersikap progresif dan berani menerapkan prinsip-prinsip perlindungan dan pengelolaan lingkungan hidup, ${ }^{20}$ pada praktiknya belum banyak hakim yang menerapkannya dengan optimal. Minimnya pertimbangan hakim atas pemulihan dapat menimbulkan permasalahan yang sama atas pelaksanaan atau eksekusi putusan lingkungan hidup, karena sesungguhnya pelaksana atau eksekutor dari putusan pidana adalah jaksa. Lantas timbul pertanyaan bagaimana jaksa akan melaksanakan atau mengeksekusi perbaikan akibat tindak pidana lingkungan hidup, apakah jaksa hanya akan menerima biaya pemulihan dari terpidana dan pemulihan dilaksanakan oleh tim ahli ataukah jaksa akan mengawasi pelaksanaan pemulihan yang dilakukan oleh terpidana. Terlebih, dengan hanya berpatokan pada cara formal (pemberian kompos pada 40 hektare lahan yang terbakar) dan valuasi biaya (Rp15.141.826.779,325), tidak ada jaminan bagi lingkungan hidup yang terbakar akan pulih seperti sedia kala sebelum terbakar karena tidak ada indikator yang ditetapkan. Singkatnya, penegakan hukum pidana korporasi dalam perkara lingkungan hidup belum berorientasi pada pemulihan.

\footnotetext{
${ }^{18}$ Lembaga Kajian dan Advokasi Independensi Peradilan (LeIP), “Kertas Kebijakan Penguatan Sistem Eksekusi Sengketa Perdata di Indonesia," (Jakarta: LeIP, 2019) hlm. 144.

${ }^{19}$ Pengadilan Negeri Pelalawan, Putusan No. 228/Pid.Sus/2013/PN.Plw, hlm. 213-216.

${ }^{20}$ Indonesia, Ketua Mahkamah Agung, Keputusan No. 36/KMA/SK/II/2013, "Pedoman Penanganan Perkara Lingkungan Hidup," Pendahuluan.
} 


\section{Perjanjian Penangguhan Penun- tutan sebagai Solusi Alternatif Pertanggungjawaban Pidana Korporasi dalam Perkara Ling- kungan Hidup}

\section{A. Perjanjian Penangguhan Penun- tutan sebagai Jalan Pintas Pene- gakan Hukum Pidana Berorien- tasi Pemulihan}

Deffered Prosecution Agreement (DPA) atau Perjanjian Penangguhan Penuntutan adalah konsep baru yang berkembang di Amerika Serikat dan Inggris untuk mengefektifkan pertanggungjawaban pidana korporasi yang rumit, lama, dan mahal. Perjanjian Penangguhan Penuntutan merupakan kesepakatan yang dilakukan oleh jaksa penuntut umum dan terdakwa korporasi atau kuasa hukumnya untuk mengalihkan penuntutan atau untuk menangani kesalahan korporasi melalui prosedur pemulihan administratif atau sipil ${ }^{21}$ dengan syarat menyelesaikan beberapa kewajiban sebagai konsekuensi dari tindak pidana yang dilakukan oleh korporasi. ${ }^{22}$ Saat ini, Perjanjian Penangguhan Penuntutan telah menjadi metode standar untuk menye- lesaikan tindak pidana korporasi federal mayor, yang ditandai dengan terbitnya Memorandum Thompson yang telah mengalami beberapa perubahan dan sekarang tercakup dalam Attorney's Manual Amerika Serikat. ${ }^{23}$

Lebih lanjut, Pedoman Departemen of Justice (DOJ) menjelaskan ketentuanketentuan yang biasa dijumpai dalam Perjanjian Penangguhan Penuntutan, sebagai berikut: ${ }^{4}$

1) Pembacaan dugaan tindak pidana dan/atau pengakuan kesalahan;

2) Janji untuk bekerjasama dengan jaksa penuntut umum;

3) Janji untuk beroperasi secara sah;

4) Mengesampingkan pembatasan undang-undang;

5) Mengesampingkan hak-hak untuk persidangan yang cepat;

6) Pengakuan bahwa perjanjian tidak mengikat lembaga federal lainnya;

7) Pengakuan bahwa perjanjian terbuka untuk umum;

8) Ketentuan yang menyatakan bahwa pernyataan karyawan perusahaan atau agen tidak akan

\footnotetext{
${ }^{21}$ Polly Sprenger, Deffered Prosecution Agreement: The Law and Practice of Negotiated Corporate Criminal Penalties, (London: Sweet \& Maxwell, 2014), hlm. 77.

${ }^{22}$ Kedua konsep ini juga berbeda dengan plea agreement, dimana perusahaan mengakui kesalahannya terlebih dahulu sebelum melaksanakan kewajiban yang dituangkan dalam perjanjian. Lihat Delaney, Op. Cit.

${ }^{23}$ Joseph G. Block dan David L. Feinberg, "Look Before You Leap: DPA, NPAs, And the Environmental Criminal Case", ALI-ABA Business Law Course Materials Journal, (Februari 2010), hlm. 8.

${ }^{24}$ Ibid., hlm. 9. Lihat juga Cindy R. Alexander dan Mark A. Cohen, Trends in the Use of Non-Prosecution, Deferred Prosecution, and Plea Agreement in the Settlement of Alleged Corporate Criminal Wrongdoing, (Arlington: Law and Economics Center George Mason University School of Law, 2015), hlm. 27.
} 
bertentangan dengan perjanjian;

9) Ketentuan yang menyatakan pelanggaran akan menjadi alasan untuk penuntutan dan pernyataan fakta-fakta dalam perjanjian, yang membenarkan kesalahan akan diterima;

10) Perjanjian Penangguhan Penuntutan juga sering kali mencakup ketentuan pelayanan masyarakat, pidana denda, pengawasan korporasi, dan dalam beberapa kasus pengenyampingan hakhak istimewa.

Secara sederhana Perjanjian Penangguhan Penuntutan dapat dikatakan sebagai pidana percobaan "unofficial probation" bagi korporasi. ${ }^{25}$ Paling tidak ada 3 tahap proses Perjanjian Penangguhan Penuntutan, yaitu: 1) negosisasi: tahap ini dilakukan pada pendakwaan, dimana jaksa penuntut umum akan mengungkapkan fakta-fakta, kemudian menawarkan suatu penundaan penuntutan kepada terdakwa korporasi atau kuasa hukumnya, dengan syarat korporasi tersebut mengakui tindak pidana yang dilakukannya dan sepakat untuk membayar pidana denda serta syaratsyarat lainnya (pemulihan, penggantian kerugian, restitusi, program ketaatan korporasi, penunjukan pengawas atau penasihat korporasi, ${ }^{26}$ atau mekanisme pencegahan perbuatan serupa di kemudian hari); 2) persetujuan: pada tahap ini jaksa penuntut umum akan meminta hakim independen untuk menilai klausula Perjanjian Penangguhan Penuntutan apakah sudah mencerminkan keadilan, rasionalitas, dan proporsionalitas; dan 3) penegakan: jika semua syarat dalam Perjanjian Penangguhan Penuntutan dipenuhi maka dakwaan akan dibatalkan ${ }^{27}$ melalui penetapan pengadilan, ${ }^{28}$ namun ketika jaksa penuntut umum menemukan korporasi tidak mematuhi perjanjian tersebut maka jaksa penuntut umum dapat meminta peninjauan kembali dari hakim independen. ${ }^{29}$

Lebih lanjut, tahap penegakan Perjanjian Penangguhan Penuntutan ini menarik karena terdapat penunjukan auditor perusahaan independen untuk me-

\footnotetext{
${ }^{25}$ Grasso Costantino, "Peaks and Troughs of the U.K. Deferred Prosecution Agreement: The Lesson Learned from the First-Ever DPA between the SFO and ICBC SB PLC," Journal of Business Law, Sweet and Maxwell (Forthcoming); Queen Mary School of Law Legal Studies Research Paper No. 223/2016, (March 16, 2016), hlm. 2.

26 "Deferred Prosecution for Individuals," https://www.breedinglaw.com/Articles/Deferredprosecution-for-individuals.shtml, diakses pada 20 november 2019. Lihat juga Sharon Oded, "Deffered Prosecution Agreement," The Journal for Social Justice, Vol. 2 (2011), hlm. 5-6.

${ }^{27}$ Ibid.

${ }^{28}$ Morgan Lewis, "Deferred Prosecution Agreements: Key Differences Between the US and UK", dalam https://www.marsh.com/us/insights/research/deferred-prosecution-agreements-key-differences-between-the-us-and-uk.html, diakses pada 30 Januari 2019.

${ }^{29}$ Michael Bisgrove dan Mark Weeks, "Deferred Prosecution Agreement: A Practical Consideration," Crim. L.R., Issue 6 (2014), hlm. 428-429.
} 
mantau kepatuhan perusahaan terhadap Perjanjian Penangguhan Penuntutan. Penggunaan auditor independen dalam Perjanjian Penangguhan Penuntutan, termasuk pembagian peran dan tanggung jawabnya menjadi diskresi jaksa penuntut umum. Meskipun penunjukan auditor perusahaan berasal dari perjanjian antara korporasi dan jaksa, korporasi setuju bahwa penunjukan pengawas ini hanya untuk menghindari konsekuensi penuntutan. Berdasarkan pendekatan ini, jika perusahaan memiliki manajemen kepatuhan yang baik dan komprehensif, maka auditor perusahaan ini tidak diperlukan. Di banyak kasus, auditor ini dipilih dari mantan aparat penegak hukum, termasuk mantan hakim, jaksa, dan pejabat pembuat kebijakan yang dianggap dapat dipercaya oleh semua pihak dalam Perjanjian Penangguhan Penuntutan. ${ }^{30}$

Sayangnya, tidak semua tindak pidana dapat menempuh prosedur Perjanjian Penangguhan Penuntutan, melainkan terbatas pada tindak pidana yang ditentukan undang-undang saja. Contohnya, di Amerika Serikat sering diterapkan pada tindak pidana pencucian uang, korupsi, penipuan perbankan, penipuan pajak, penipuan layanan kesehatan, lingkungan hidup, dan sebagainya. ${ }^{31}$ Sementara di Inggris dan Wales hanya untuk tindak pidana ekonomi. ${ }^{32}$ Sedangkan, di Australia Perjanjian Penangguhan Penuntutan terbatas untuk tindak pidana keamanan negara, urusan luar negeri atau pelanggaran urusan/kepercayaan publik. $^{33}$

Selain itu, Perjanjian Penangguhan Penuntutan memiliki beberapa konsekuensi kolateral. Pertama, terdakwa wajib membuka informasi proses hukum kepada publik, terutama jika ia adalah perusahaan terbuka maka ia harus megikuti pelaporan kepada Securities and Exchange Committee (SEC). ${ }^{34}$ Hal ini juga diatur dalam butir 103 tentang keterbukaan proses hukum (17C.F.R.\$229.103(2009) yang mengharuskan pembukaan materi proses hukum yang tertunda yang tidak biasa dan rutin bagi bisnis. ${ }^{35}$ Lebih rinci, butir 103 berisi bahasa khusus yang ditujukan kepada proses administrasi dan hukum yang (i) timbul dalam hukum apapun yang mengatur pelepasan materi ke lingkungan hidup atau (ii) timbul dalam hukum apapun yang diterbitkan dengan tujuan melindungi lingkungan

\footnotetext{
${ }^{30}$ Jennifer O'Hare, “The Use of the Corporate Monitor in SEC Enforcement Actions”, Brooklyn Journal of Corporate, Financial \& Commercial Law, Vol. 1, (2006), hlm. 108.

${ }^{31}$ Joseph G. Block dan David L. Feinberg, Op. Cit., hlm. 8.

32 "Deferred Prosecution for Individuals," Op.Cit., dan Sharon Oded, Op.Cit.

${ }^{33}$ Ibid.

${ }^{34}$ Ibid., hlm. 11.

${ }^{35}$ Ibid., hlm. 12.
} 
hidup. ${ }^{36}$ Proses persidangan harus dibuka jika: ${ }^{37}$

1) prosesnya material untuk bisnis atau kondisi keuangan dari pendaftar; atau

2) proses utamanya melibatkan sebuah tuntutan ganti kerugian atau melibatkan potensi sanksi moneter atau pengeluaran modal atau pembebanan biaya pada pendapatan - yang melebihi 10 persen dari asset perusahaan saat ini dan anak perusahaannya; atau

3) sebuah otoritas pemerintahan adalah salah satu pihak dan prosesnya melibatkan potensi sanksi moneter kecuali perusahaan percaya bahwa proses hukum tidak akan menghasilkan sanksi moneter atau sanksi moneter, bunga eksklusif, dan biaya-biaya kurang dari $\$ 100.000$.

Di samping itu, butir 303 mengkhususkan persyaratan bagi perusahaan melakukan "analisis manajemen dan diskusi," sebuah penjelasan naratif yang mendampingi laporan keuangan. Butir 303 mensyaratkan keterbukaan dan diskusi dari setiap komitmen yang diketahui akan memiliki dampak material kepada kondisi keuangan sebuah perusahaan atau hasil dari sebuah operasi. ${ }^{38}$

\footnotetext{
${ }^{36} \mathrm{Ibid}$.

${ }^{37} \mathrm{Ibid}$.

${ }^{38}$ Ibid., hlm. 13.

${ }^{39} \mathrm{Ibid}$.

${ }^{40}$ Ibid., hlm. 20.
}

Kedua, Perjanjian Penangguhan Penuntutan menyediakan peluang untuk digugat secara perdata. Ketiga, bagi perusahaan yang melakukan bisnis dengan pemerintah dapat dikenakan penskorsan dan larangan mengikuti lelang atau bekerjasama dengan pemerintah atau mendapatkan pinjaman atau hibah atau pendampingan dari pemerintah. ${ }^{39}$

Dalam beberapa kasus, pelanggar hukum lingkungan hidup membuka pelanggaran mereka secara sukarela kepada EPA atau DOJ. Hal ini menjadi panduan bagi jaksa penuntut umum untuk menilai kelayakan penggunaan Perjanjian Penangguhan Penuntutan. Adapun hal-hal yang dipertimbangkan antara lain: ${ }^{40}$

1) kualitas keterbukaan perusahaan dan apakah dilakukan sebelum penyidik menemukan ketidaktaatan;

2) kualitas atas kerjasama perusahaan dalam penyidikan;

3) keberadaan, kualitas, dan lingkup program ketaatan lingkungan yang sudah ada dan apakah hal tersebut memperlihatkan komitmen ketaatan lingkungan yang kuat;

4) penyebaran ketidaktaatan, keberadaan dan penggunaan pro- 
sedur disiplin internal, dan berbagai usaha untuk memulihkan ketidaktaatan yang terjadi.

Jika perusahaan tidak membuka pelanggaran secara sukarela, maka berdasarkan Prinsip Penuntutan Federal Badan Usaha, jaksa penuntut umum harus mengevaluasi faktor-faktor sebagai berikut: ${ }^{41}$

1) sifat alami dan keseriusan pelanggaran;

2) penyebaran kesalahan dalam perusahaan;

3) sejarah korporasi atas tindakan yang mirip;

4) keterbukaan perusahaan secara berkala dan sukarela atas kesalahan dan kemauannya bekerjasama dalam penyidikan agennya;

5) keberadaan dan kecukupan program ketaatan perusahaan yang sudah ada;

6) tindakan perbaikan perusahaan;

7) konsekuensi kolateral atas pemegang saham, karyawan, pemegang pension, dan dampak publik penuntutan;

8) kecukupan atas penuntutan penanggung jawab individu atas penyimpangan perusahaan;

9) kecukupan atas perbaikan seperti gugatan perdata atau penegakan peraturan.

\footnotetext{
${ }^{41}$ Ibid., hlm. 20-21.
}

Jadi, terdapat persyaratan yang ketat untuk menempuh Perjanjian Penangguhan Penuntutan. Perjanjian Penangguhan Penuntutan memerlukan komitmen jangka panjang dan kesungguhan korporasi dalam pelaksanaannya. Oleh karena itu, Perjanjian Penangguhan Penuntutan dapat menjadi menjadi salah satu solusi alternatif untuk mewujudkan peradilan yang cepat, mudah, berbiaya ringan, dan berorientasi pada pemulihan. Ia juga dapat berperan sebagai instrumen pencegahan terulangnya perbuatan perusakan dan/atau pencemaran di masa depan. Lebih banyak tentang Perjanjian Penangguhan Penuntutan dalam konteks lingkungan hidup akan dibahas pada bagian selanjutnya.

\section{B. Potensi penerapan Perjanjian Penangguhan Penuntutan da- lam Pertanggungjawaban Pida- na Korporasi dalam Perkara Lingkungan Hidup di Indonesia}

Berdasarkan pembahasan sebelumnya diketahui bahwa penegakan hukum pidana lingkungan hidup korporasi memakan waktu yang cukup lama dan belum berorientasi pada pemulihan lingkungan hidup walaupun dijatuhkan denda yang sangat besar. Perjanjian Penangguhan Penuntutan dapat menjadi solusi alternatif untuk memecahkan masalah tersebut, tidak hanya karena 
mekanismenya yang relatif lebih cepat, jelas, dan dapat mencapai tujuan perlindungan dan pelestarian lingkungan hidup melalui pemulihan, tetapi Perjanjian Penangguhan Penuntutan juga menyediakan insentif bagi perusahaan dengan mengurangi reputasi buruk untuk berkomitmen dalam menjaga lingkungan hidup.

Contoh penerapan Perjanjian Penangguhan Penuntutan dalam perkara lingkungan hidup dapat ditemukan di dua kasus berikut. Pada 20 Januari 2006, First Energy - sebuah perusahaan nuklir - menyelesaikan dugaan tindak pidana melalui Perjanjian Penangguhan Penuntutan. Ia diduga membuat pernyataan tidak benar bahwa pembangkit listrik tenaga nuklir di Toledo, Ohio, aman beroperasi. Tindakan ini melanggar Regulasi Komisi Nuklir. Hal-hal yang menarik dalam perjanjian tersebut antara lain: First Energy diharuskan membayar pidana denda sebesar $\$ 23$ juta, proyek pengabdian masyarakat sebesar $\$ 4,3$ juta (pendanaan restorasi lahan basah sebesar $\$ 800.000$ di National Wildlife Refugee Ottawa, peningkatkan pusat kunjungan pengungsi sebesar $\$ 550.000$, peningkatan sistem komunikasi Asosiasi Manajemen Kedaruratan Wilayah Ottawa sebesar $\$ 500.000$, pengembangan teknologi efisiensi energi di Universitas Toledo sebesar $\$ 500.000$, dan perpan- jangan jalan setapak di Taman Nasional Lembah Cuyahoga sebesar $\$ 1$ juta), dan ganti rugi perdata sebesar $\$ 5,4$ juta. Selain itu, Perjanjian Penangguhan Penuntutan juga mengharuskan First Energy mendampingi DOJ dalam menuntut karyawannya. Perjanjian Penangguhan Penuntutan First Energy juga mengandung ketentuan non-kontradiksi yang menyatakan bahwa perusahaan tidak akan menyatakan penyangkalan kepada publik atas apa yang tertulis dalam dokumen perjanjian. ${ }^{42}$

Selanjutnya, pada 8 Februari 2006, Operation Management International (OMI) - sebuah perusahaan pengelolaan air limbah - menyelesaikan pelanggaran undang-undang air bersih di Distrik Connecticut, tepatnya di fasilitas yang berada di New Haven dan Norwalk, melalui Perjanjian Penangguhan Penuntutan. OMI diduga melakukan pelaporan selektif dengan hanya melaporkan sampel bersih saja tanpa melaporkan sampel kotor. Hal-hal yang menarik dalam perjanjian tersebut antara lain: OMI setuju untuk melakukan pemeriksaan operasi ketaatan komprehensif secara nasional sebesar \$6 juta, yang termasuk penambahan karyawan dan sumber daya yang berdedikasi untuk ketaatan lingkungan, menyediakan pelatihan ketaatan tambahan untuk karyawan OMI, dan menjadwalkan audit di seluruh 116 fasilitas

\footnotetext{
${ }^{42}$ Joseph G. Block dan David L. Feinberg, Op. Cit., hlm. 9-10.
} 
OMI. Selain itu, OMI membersihkan fasilitas di Connecticut, memberhentikan para manajer, dan memasang peralatan terbaru. OMI juga setuju untuk membentuk pengawasan perusahaan, audit fasilitas di Connecticut setiap 3 bulan sekali selama 2 tahun dan menyerahkan salinan hasil audit ke jaksa penuntut umum. Di samping itu, OMI setuju untuk memberikan donasi sebagai pengabdian masyarakat sebesar \$2 juta yang terdiri dari \$1 juta untuk mengelola studi lingkungan di Akademi Penjaga Pantai Amerika Serikat dan $\$ 1$ juta untuk Pengawas Pengendali Polusi Air New Haven. ${ }^{43}$

Kedua contoh kasus di atas menggambarkan bagaimana Perjanjian Penangguhan Penuntutan dapat memberikan beberapa kewajiban, baik pidana pokok, perdata, konsekuensi kolateral, maupun kewajiban lain. Berbagai sanksi yang diberikan kepada dua perusahaan tersebut pun telah berorientasi pada perlindungan dan pengelolalan lingkungan hidup jangka panjang yang sistematis. Hal menarik lainnya adalah walaupun kasus First Energy merupakan kasus pemberian pernyataan tidak benar, ia tetap dikenakan sanksi berupa compensatory restoration untuk merestorasi lahan basah.
Lebih jauh, sebuah penelitian menunjukkan bahwa 97,41 persen dari 271 perusahaan yang menempuh Perjanjian Penangguhan Penuntutan dari tahun 1993 hingga 2013 menghasilkan perubahan signifikan terhadap tata kelola perusahaan tersebut. ${ }^{44}$ Hal ini berdampak positif pada pencegahan kerusakan dan/atau pencemaran lingkungan hidup di masa mendatang, sebagaimana dicontohkan pada dua kasus di atas. Pengawasan pelaksanaan Perjanjian Penangguhan Penuntutan yang ketat dan perubahan tata kelola perusahaan yang sistematis mau tidak mau akan mengubah budaya korporasi untuk sungguh-sungguh melaksanakan Perjanjian Penangguhan Penuntutan dan berhati-hati dalam beroperasi agar kesalahan yang sama tidak terulang.

Tentunya, penerapan mekanisme Perjanjian Penangguhan Penuntutan memerlukan perubahan dalam sistem peradilan pidana di Indonesia. RKUHAP telah memberikan peluang yang diatur dalam Pasal 199 mengenai jalur khusus. Pasal ini memungkinkan pengalihan sidang ke acara singkat untuk terdakwa yang mengaku bersalah secara sukarela atas perbuatannya melakukan tindak pidana yang ancaman pidana yang didakwakan kepadanya tidak lebih dari 7 ta-

\footnotetext{
${ }^{43}$ Ibid., hlm. 11.

${ }^{44}$ June Rhee, "The Effect of Deferred and Non-Prosecution Agreements on Corporate Governance", The Business Lawyer, Vol. 70, (November 2014), hlm. 9.
} 
hun. Pengakuan tersebut terlebih dahulu dituangkan dalam berita acara. Pada persidangan acara singkat, hakim wajib a) memberitahukan kepada terdakwa mengenai hak-hak yang dilepaskan, b) memberitahukan lamanya pidana yang kemungkinan dikenakan, dan c) menanyakan apakah pengakuan diberikan secara sukarela. Pidana yang dijatuhkan melalui mekanisme ini tidak boleh melebihi 2/3 dari ancaman pidana maksimal tindak pidana yang didakwakan. Secara teori, mekanisme ini dapat dipadankan dengan Plea Bargaining System dengan bentuk plea agreement. ${ }^{45}$ Meskipun berbeda, pada dasarnya plea agreement dan Perjanjian Penangguhan Penuntutan, sama-sama merupakan perjanjian pengalihan (diversion agreement).

Lebih lanjut, Perjanjian Penangguhan Penuntutan sudah dapat dimulai sejak proses pra-ajudikasi yaitu di tahap dakwaan, bisa dilakukan saat P-19 atau P-21. Tepatnya, setelah penyidik menyerahkan berkas perkara kepada penuntut umum, saat itulah proses negosiasi dan perancangan Perjanjian Penangguhan Penuntutan dimulai.

Kemudian, para pihak melakukan negosiasi yang berfokus pada kerusakan dan/atau pencemaran lingkungan hidup yang terjadi dan mekanisme pemulihan- nya yang mencakup angka waktu pemulihan, Identifikasi komponen lingkungan hidup yang rusak dan/atau tercemar, upaya pemulihan yang akan dilaksanakan dan biaya pemulihan, lokasi pelaksanaan upaya pemulihan, standar untuk masing-masing ekosistem dikatakan pulih, dan mekanisme pengawasan. Untuk itu diperlukan bantuan ahli ekologis dan ekonomi, karena setiap ekosistem memiliki keunikan tersendiri dan terdapat berbagai metode yang dapat digunakan baik untuk menghitung kerusakan lingkungan hidup ataupun untuk memulihkan kerusakan lingkungan hidup. Selain itu dalam negosiasi juga dibicarakan mengenai konsekuensi kolateral, seperti publikasi proses hukum, pengawasan, pencabutan hak-hak tertentu (pinjaman bank, penerima hibah, dan lain sebagainya), dan perbaikan tata kelola perusahaan. Dalam RKUHAP juga terdapat hakim pemeriksa pendahuluan yang dapat berperan dalam proses Perjanjian Penangguhan Penuntutan ini. ${ }^{46}$

Di samping itu, Perjanjian Penangguhan Penuntutan juga harus diatur dalam hukum pidana materiel karena berkaitan dengan gugurnya hak menuntut dan pengulangan tindak pidana/recidiv. Di satu sisi KUHP kita sudah mengenal afdoening buiten process atau penyelesai-

${ }^{45}$ Ichsan Zikry, Gagasan Plea Bargaining System Dalam RKUHAP dan Penerapan di Berbagai Negara, dalam https:// bantuanhukum.or.id/konten/Gagasan-Plea-Barganing-Dalam-RKUHAP.pdf, diakses pada 30 Januari 2019.

${ }^{46}$ Indonesia, Rancangan Undang-Undang tentang Hukum Acara Pidana, Pasal 111-122. 
an di luar pengadilan sebagai hal yang menggugurkan penuntutan tetapi hanya berlaku bagi pelanggaran saja. ${ }^{47} \mathrm{Di}$ sisi lain, Perjanjian Penangguhan Penuntutan hanya dapat dilakukan kepada perusahaan yang belum pernah dijatuhi hukuman atau belum pernah melakukan perjanjian, maka dari itu perlu diatur mengenai daftar terpidana korporasi atau daftar pihak Perjanjian Penangguhan Penuntutan di dalam RKUHP. ${ }^{48}$ Lebih lanjut, ternyata RKUHP per 24 September 2019 sudah memuat beberapa aspek yang perlu dipertimbangkan dalam memidana korporasi yang mirip dengan pertimbangan apakah terdakwa korporasi dapat melakukan Perjanjian Penangguhan Penuntutan, yaitu: ${ }^{49}$

1) tingkat kerugian atau dampak yang ditimbulkan;

2) tingkat keterlibatan pengurus yang mempunyai kedudukan fungsional korporasi dan/atau peran pemberi perintah, pemegang kendali, pemberi perintah, dan/atau pemilik manfaat korporasi;

3) lamanya tindak pidana yang telah dilakukan;
4) frekuensi tindak pidana oleh korporasi;

5) bentuk kesalahan tindak pidana;

6) keterlibatan pejabat;

7) nilai hukum dan keadilan yang hidup dalam masyarakat;

8) rekam jejak korporasi dalam melakukan usaha atau kegiatan;

9) pengaruh pemidanaan terhadap korporasi; dan/atau

10) kerja sama korporasi dalam penanganan tindak pidana.

Namun demikian, mekanisme Perjanjian Penangguhan Penuntutan tidak akan bekerja dengan baik apabila para pihak tidak memiliki integritas yang baik. Aparat hukum di Indonesia masih rentan terhadap penyalahgunaan wewenang dan korporasi masih tidak taat terhadap pelaporan mandiri/self-reporting. Aparat penegak hukum yang terlibat dalam proses Perjanjian Penangguhan Penuntutan memerlukan petunjuk pelaksanaan dan kode etik dalam beracara melalui mekanisme ini. Kebalikannya, jika Perjanjian Penangguhan Penuntutan dijalankan dengan baik ia dapat menjadi solusi alternatif yang saling menguntungkan bagi negara dan korporasi.

\footnotetext{
${ }^{47}$ Kitab Undang-Undang Hukum Pidana [Wetboek van Straftrecht], diterjemahkan oleh Moeljatno, (Jakarta: Pradnya Paramita, 1996), Pasal. 82 KUHP.

${ }^{48}$ Febby Mutiara Nelson, "Peradilan Sederhana, Cepat, dan Biaya Ringan: Menggagas Penanganan Tindak Pidana Korpusi Melalui Konsep Plea Bargaining dan Deffered Prosecution Agreement”, (Ringkasan Disertasi Dokter Universitas Indonesia, Depok, 2019), hlm. 81.

${ }^{49}$ Indonesia, Rancangan Undang-Undang tentang Kitab Undang-Undang Hukum Pidana, 24 September 2019, Pasal 56.

${ }^{50}$ Ryan McConnell dan Jay Martin, "Plan Now or Pay Later: The Role of Compliance in Criminal Cases”, Houston Journal of International Law, Vol. 33, No. 3 (2011), hlm. 102.
} 
Negara mendapat manfaat dengan pembayaran denda, berkurangnya tumpukan kasus di pengadilan, dan pemulihan lingkungan hidup yang lebih cepat. Di sisi lain, korporasi tetap menerima konsekuensi akibat tindak pidana yang diperbuatnya berupa pembayaran denda dan pembebanan kewajiban-kewajiban lainnya, tetapi tidak terlalu kehilangan reputasi karena perkara tidak memakan waktu yang lama sebagaimana proses ajudikasi biasa, karyawan korporasi pun tidak menjadi korban pemutusan hubungan kerja karena perusahaan tidak runtuh dan tidak jatuh sahamnya. Bahkan publikasi dan perbaikan tata kelola perusahaan dapat meningkatkan reputasi perusahaan. Perusahaan dengan reputasi praktik bisnis dan tata kelola perusahaan yang baik (good corporate governance) cenderung memiliki nilai saham yang tinggi. ${ }^{51}$

\section{Penutup}

Hasil eksplorasi pada tulisan ini menunjukkan adanya kemungkinan pengaplikasian konsep Perjanjian Penangguhan Penuntutan dalam penegakan hukum pidana lingkungan hidup di Indonesia. Hal ini sebagaimana didukung dari hasil evaluasi pertanggungjawaban pidana korporasi dalam 8 kasus lingkungan hidup yang telah diputus (baik yang telah berkekuatan hukum tetap maupun belum) sepanjang tahun 2010 sampai 2019 yang menunjukkan proses penegakan hukum memakan waktu yang lama dan belum berorientasi pada pemulihan.

Perjanjian Penangguhan Penuntutan dapat menjadi solusi alternatif atas masalah tersebut. Di negara asalnya, mekanisme ini banyak membawa manfaat baik dalam penegakan hukum pidana arus utama maupun lingkungan hidup. Dari sini terlihat bahwa mekanisme Perjanjian Penangguhan Penuntutan menjanjikan peluang besar mewujudkan cita-cita UU PPLH.

Terkait hal tersebut, Indonesia perlu melakukan revisi sistem peradilan pidana. Revisi sistem ini dapat dimulai dari KUHAP dan KUHP agar mengatur mekanisme Perjanjian Penangguhan Penuntutan. Mengingat perdebatan perbedaan

${ }^{51}$ Ryan McConnell dan Jay Martin, "Plan Now or Pay Later: The Role of Compliance in Criminal Cases”, Houston Journal of International Law, Vol. 33, No. 3 (2011), hlm. 102. 
sistem hukum tidak seharusnya menjadi perdebatan lagi. Hal ini karena konvergensi antar sistem hukum sudah lumrah terjadi, bahkan di Indonesia, yang ditunjukan dengan diadopsinya mekanisme jalur khusus seperti plea agreement dalam RKUHAP.

Akhir kata, Perjanjian Penangguhan Penuntutan dapat menjadi solusi alternatif untuk menciptakan efektivitas dan efisiensi penegakan hukum pidana lingkungan yang cepat, mudah, berbiaya ringan, dan berorientasi pada pemulihan, serta tidak hanya bermanfaat bagi penegakan hukum pidana lingkungan hidup tetapi juga korporasi itu sendiri. 


\section{DAFTAR PUSTAKA}

\section{Peraturan Perundang-undangan:}

Kitab Undang-Undang Hukum Pidana [Wetboek van Straftrecht], diterjemahkan oleh Moeljatno. Jakarta: Pradnya Paramita. 1996.

Indonesia. Undang-Undang Perlindungan dan Pengelolaan Lingkungan Hidup. UU No. 32 Tahun 2009. LN No. 140 Tahun 2009. TLN No. 5059.

. Undang-Undang tentang Penerimaan Negara Bukan Pajak. UU No. 9 Tahun 2018. LN No. 147 Tahun 2018. TLN No. 6245.

Peraturan Pemerintah tentang Jenis dan Tariff Atas Jenis Penerimaan Negara Bukan Pajak Yang Berlaku Pada Kejaksaan Republic Indonesia. PP No. 39 Tahun 2016.

. Ketua Mahkamah Agung, Keputusan No. 36/KMA/SK/II/ 2013. "Pedoman Penanganan Perkara Lingkungan Hidup." Pendahuluan.

. Rancangan Undang-Undang tentang Hukum Acara Pidana.

. Rancangan Undang-Undang tentang Kitab Undang-Undang Hukum Pidana, 24 September 2019.

\section{Putusan:}

Pengadilan Negeri Pelalawan. Putusan No. 228/Pid.Sus/2013/PN.Plw.

\section{Buku:}

Alexander, Cindy R. dan Mark A. Cohen. Trends in the Use of Non-Prosecution,
Deferred Prosecution, and Plea Agreement in the Settlement of Alleged Corporate Criminal Wrongdoing. Arlington: Law and Economics Center George Mason University School of Law. 2015.

Arief, Barda Nawawi. Bunga Rampai Kebijakan Hukum Pidana. Bandung: Citra Aditya Bakti. 1996.

Cane, Peter. Responsibility in Law and Morality. United Kingdom: Hart Publishing. 2002.

Hatrik, Hamzah. Asas Pertanggungjawaban Korporasi dalam Hukum Pidana Indonesia. Jakarta: Raja Grafindo Persada. 1995.

Hoefnagels, G. Peter. The Other Side of Criminology. Deventer, Hollend: Kluwer. 1973.

Keraf, Sony. Etika Lingkungan Hidup. Jakarta: PT Kompas Media Nusantara. 2010

Maradona, "Penegakan Hukum Lingkungan: Administrasi dan Pidana" dalam Laode M Syarif dan Andri G Wibisana, ed., Hukum Lingkungan Teori, Legislasi, dan Studi Kasus, s.1.: USAID-Kemitraan Partnership-the Asia Foundation, 2015.

Muladi dan Barda Nawawi Arief. Teoriteori dan Kebijakan Pidana. Bandung: Citra Aditya Bakti. 1996.

Muladi dan Dwija Priyatno. Pertanggungjawaban Pidana Korporasi. Jakarta: Kencana Pernada Media Group. 2008.

Posner, Richard A. Economic Analysis of 
Law, Edisi ke-3. s.l.: Wolter Kluwer. 1986.

Rahmadi, Takdir. Hukum Lingkungan di Indonesia, Cetakan ke-4. Jakarta: PT Raja Grafindo Persada. 2014.

Reksodiputro, Mardjono. Kejahatan Kegiatan Perbankan. Jakarta: Pusat Pelayanan Keadilan dan Pengabdian $\mathrm{Hu}-$ kum. 2007.

Sprenger, Polly. Deffered Prosecution Agreement: The Law and Practice of Negotiated Corporate Criminal Penalties. London: Sweet \& Maxwell. 2014.

\section{Artikel}

Anderson, Elizabeth S. dan Richard H. Pidles, "Expressive Theories of Law: A General Restatement," University of Pennsylvania Law Review, Vol. 148, 2000.

Bisgrove, Michael dan Mark Weeks. “Deferred Prosecution Agreement: A Practical Consideration," Crim. L.R. Issue 6 (2014).

Block, Joseph G. dan David L. Feinberg. "Look Before You Leap: DPA, NPAs, And the Environmental Criminal Case," ALI-ABA Business Law Course Materials Journal, Februari 2010.

Cohen, Mark A., "Environmental Crime and Punishment: Legal/Economic Theory and Empirical Evidence on Enforcement of Federal Environmental Statutes," The Journal of Criminal Law and Criminology, Vol. 82, No. 4. 1992.

Costantino, Grasso. "Peaks and Troughs of the U.K. Deferred Prosecution Ag- reement: The Lesson Learned from the First-Ever DPA between the SFO and ICBC SB PLC." Journal of Business Law. Sweet and Maxwell (Forthcoming). Queen Mary School of Law Legal Studies Research Paper No. 223/2016. (March 16, 2016).

Delaney, Rachel. "Congressional Legislation: The Next Step for Corporate Deferred Prosecution Agreements," Marquette Law Review, Vol. 93 No. 2, 2009.

Elkins, James R., "Corporations and the Criminal Law - An Uneasy Alliance," Kentucky Law Journal, Vol. 65, No. 1, 1977.

Farrokhi, Mehrdad, et. al., “Approaches to Post-disaster Environmental Recovery," Health in Emergency and Disasters Quarterly. Vol. 1, No. 2 (2016), hlm. 66.

Fischel, Daniel R. dan Alan O. Sykes, "Corporate Crime," The Journal of Legal Studies, Vol. 25, No. 2, Juni 1996.

Husin, Sukanda. "Peranan Hukum Pidana dalam Memerangi Kejahatan Lingkungan di Indonesia," Jurnal Hukum dan Pembangunan, Vol. 25, No. 6, Desember 1995.

Loeqman, Loebby. “Tanggung Jawab Pidana Korporasi dalam Tindak Pidana Lingkungan Hidup," Jurnal Hukum dan Pembangunan, Vol. 19, No. 3, 1989.

McConnell, Ryan dan Jay Martin. "Plan Now or Pay Later: The Role of Compliance in Criminal Cases," Houston Journal of International Law, Vol. 33, 
No 3, 2011.

O'Hare, Jennifer, “The Use of the Corporate Monitor in SEC Enforcement Actions," Brooklyn Journal of Corporate, Financial \& Commercial Law, Vol. 1, 2006.

Oded, Sharon. "Deferred Prosecution Agreements: Prosecutorial Balance in Times of Economic Meltdown," Law Journal for Social Justice, Vol. 2, 2011.

Posner, Richard A., "An Economic Theory of the Criminal Law," Columbia Law Review, Vol. 85, 1985.

Rhee, June, "The Effect of Deferred and Non-Prosecution Agreements on Corporate Governance," The Business Lawyer, Vol. 70, November 2014.

Warin, Joseph dan Andrew S. Boutros. “Deferred Prosecution Agreements: A View from the Trenches and a Proposal for Reform," Virginia Law Review, Vol. 93, 2007.

Wibisana, Andri Gunawan, "Kejahatan Lingkungan oleh Korporasi: Mencari Bentuk Pertanggungjawaban Korporasi dan Pemimpin/Pengurus Korporasi untuk Kejahatan Lingkungan di Indonesia," Jurnal Hukum dan Pembangunan, Vol. 46, No. 2, 2016.

\section{Lain-lain}

"Deferred Prosecution for Individuals." https://www.breedinglaw.com/Articles/Deferred-prosecution-forindividuals.shtml. diakses pada 20 November 2019.

Akhmad, Harits Tryan. "Jokowi Tak Gentar Hadapi Kasus Karhutla di In- donesia." https://www.hukumonline.com/berita/baca/1 t $\begin{array}{llllllllllllll}5 & \mathrm{c} & 4 & 9 & 7 & 9 & 3 & 5 & 8 & 6 & \mathrm{f} & 6 & 1 & /\end{array}$ debat-capres-ii-diminta-bongkarproblem-isu-lingkungan-dan-sda. diakses pada tanggal 7 Februari 2019.

Eric, Deputy Attorney General. "Memorandum for Heads of Department Components United States Attorneys: Principles of Federal Prosecution of Corporations" (June 16, 1999).

Gatra, Sandro. "Presiden Ingin ada Efek Jera bagi Pelaku Pembalak Liar." https: / / nasional.kompas.com / $\mathrm{read} / 2014 / 11 / 27 / 10312381 /$ Presiden.Ingin.Ada.Efek.Jera.bagi.Pelaku. Pembalakan.Liar. diakses tanggal 7 Februari 2019.

Ginting, Arija. Febby Mutiara Nelson, dan Topo Santoso. "The Idea of Preventing Corporate Corruption Through Deferred Prosecution Agreement (DPA) in Indonesia". (disampaikan pada 3rd International Conference on Advances in Education and Social Sciences. Istanbul, Turkey: ADVED, 9-11 Oktober 2017.

Lembaga Kajian dan Advokasi Independensi Peradilan (LeIP). "Kertas Kebijakan Penguatan Sistem Eksekusi Sengketa Perdata di Indonesia." Jakarta: LeIP. 2019.

Lewis, Morgan. "Deferred Prosecution Agreements: Key Differences Between the US and UK." https://www. marsh.com/us/insights/research/ deferred-prosecution-agreementskey-differences-between-the-us-and- 


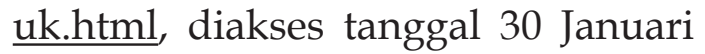
2019.

Nelson, Febby Mutiara. "Peradilan Sederhana, Cepat, dan Biaya Ringan: Menggagas Penanganan Tindak Pidana Korpusi Melalui Konsep Plea Bargaining dan Deffered Prosecution Agreement." Ringkasan Disertasi Dokter Universitas Indonesia. Depok. 2019.

NN. “4 Masalah yang Dihadapi Penyidik Kasus Lingkungan Hidup." https:/ / www.hukumonline.com/berita / baca/1t573a6ea417e97/4-masalahyang-dihadapi-penyidik-kasus-lingkungan-hidup. diakses tanggal 31 Januari 2019.

Thea, Ady. "Debat Capres II Diminta 'Bongkar' Problem Isu Lingkungan dan SDA." https://www.hukumonline.com/berita/baca/1t 5c49793586f61/debat-capres-iidiminta-bongkar-problem-isu-lingkungan-dan-sda. diakses tanggal 7 Februari 2019.

Zikry, Ichsan. “Gagasan Plea Bargaining System Dalam RKUHAP dan Penerapan di Pelbagai Negara." https:// bantuanhukum.or.id/konten/Gagasan-Plea-Barganing-Dalam-RKUHAP.pdf, diakses tanggal 30 Januari 2019. 